\title{
PENINGKATAN SEMANGAT WIRAUSAHA PASCA BENCANA GEMPA LOMBOK DI KAWASAN WISATA GILI MENO
}

\section{Enhancement of Entrepreneurship in The Lombok Earthquake Disaster in the Gili Meno Tourism Area}

\author{
Emilia Septiani*), Budi Santoso, Mulyadi, Muhdin \\ Program Studi Manajemen Universitas Mataram \\ Jl. Majapahit No. 62 mataram 83125
}

${ }^{*}$ Alamat korespondensi: emiliaseptiani@unram.ac.id

(Tanggal Submission: 28 November 2019, Tanggal Accepted: 28 Desember 2020)

\begin{abstract}
ABSTRAK
Di dalam upaya untuk mendapatkan penghasilan, cukup banyak masyarakat yang memilih untuk menjadi seorang wirausaha. Menjadi seorang wirausaha yang sukses haruslah siap dengan segala risiko, salah satunya adalah risiko kegagalan usaha. Beberapa waktu yang lalu, masyarakat Kabupaten Lombok Utara diguncang oleh gempa bumi yang cukup dahsyat dan memporak-porandakan rumah tempat tinggal maupun bangunan tempat usaha mereka. Kawasan wisata Gili Meno yang merupakan salah satu primadona wisata pantai pun terdampak. Dampak tersebut terlihat dari sepinya wisatawan yang berkunjung dan banyaknya pelaku usaha yang menutup usahanya. Sebagian masyarakat pelaku usaha di kawasan wisata Gili Meno merasakan tidak adanya semangat untuk memulai atay melanjutkan kembali usahanya. Kegiatan pengabdian ini ditujukan kepada masyarakat kawasan wisata Gili Meno dengan tujuan untuk memberikan pelatihan kewirausahaan terutama yang berkaitan dengan motivasi berwirausaha dan mencari ide usaha. Metode kegiatan yang digunakan adalah sharing informasi dan pendampingan. Hasil dari kegiatan ini menunjukkan mulai tumbuhnya semangat dari masyarakat sekitar untuk melanjutkan usahanya, bahkan membuka usaha baru. Hal tersebut terlihat dari antusiasme masyarakat yang masih bertahan di kawasan Gili Meno mengajak rekan-rekannya untuk kembali. Masyarakat kawasan Gili Meno berusaha saling tolong-menolong dalam menghidupkan kembali kegiatan usahanya. Dengan dimulainya usaha lama dan mengembangkannya, maka perlahan-lahan masyarakat kawasan wisata Gili Meno kembali memiliki penghasilan untuk menghidupi diri sendiri dan keluarganya
\end{abstract}

Kata Kunci: wirausaha, wirausaha pasca bencana, motivasi usaha dan ide usaha. 


\section{PENDAHULUAN}

Bencana gempa bumi yang terjadi di Lombok Nusa Tenggara Barat pada tanggal 5 Agustus 2018 telah memberikan dampak yang signifikan bagi kehidupan sosial-ekonomi masyarakat. Sebagian besar masyarakat yang berada di pusat gempa dan sekitarnya mengalami kerugian berupa kerusakan rumah yang parah (roboh) dan kehilangan mata pencaharian. Dampak bencana yang sangat parah dirasakan oleh masyarakat Kabupaten Lombok Utara.

Kabupaten Lombok Utara (KLU) merupakan salah satu kabupten yang terbilang baru terbentuk yang ada di wilayah Provinsi Nusa Tenggara Barat (NTB). Mata pecaharian masyarakat KLU adalah di bidang pertanian dan peternakan. KLU terkenal dengan pariwisata pantai. Salah satu primadona wisata pantai KLU adalah Kawasan Wisata 3 Gili (menurut Perda NTB No. 7 Tahun 2013 tentang KSPD Provinsi NTB).

Gili Meno tidak luput dari dampak gempa yang terjadi di Lombok apalagi lokasinya sangat dekat dengan pusta gempa. Kejadian gempa bumi yang mengguncang Pulau Lombok secara beruntun mengakibatkan lumpuhnya sektor pariwisata yang ada di Gili Meno yang pada akhirnya berdampak pada kondisi perekonomian masyarakat. Tempat-tempat penginapan dan café/rumah makan yang dimiliki oleh warga mengalami kerusakan yang sangat parah. Selain itu, warga di seluruh kawasan gili juga pergi untuk mengungsi karena trauma dan khawatir akan adanya gempa susulan. Mendadak pada saat itu masyarakat menjadi kehilangan mata pencahariannya. Berbagai upaya telah dilakukan oleh Pemerintah Daerah (Pemda) berkejasama dengan Kementerian Pariwisata (Kemenpar) untuk melakukan hal-hal yang mampu meningkatkan geliat pariwisata di Pulau Lombok, khususnya kawasan Tiga Gili.
Dengan merujuk pada kondisi tersebut, maka kegiatan yang berkaitan dengan penambahan pengetahuan mengenai kewirausahaan perlu untuk dilakukan agar masyarakat di Kawasan Wisata Gili Meno tetap optimis dalam membangun dan mengembangkan usahanya pasca bencana yang dialami. Kewirausahaan (Suryana: 2003) adalah kemampuan kreatif dan inovatif yang dijadikan dasar, kiat dan sumber daya untuk mencari peluang menuju sukses. Inti dari kewirausahaan adalah kemampuan untuk menciptakan sesuatu yang baru dan berbeda (create new and different) melalui berfikir kreatif dan inovatif. Dengan kegiatan pelatihan kewirausahaan ini diharapkan masyarakat mampu untuk bertahan bahkan dapat tergerak untuk berwirausaha sehingga dapat bertahan dari sisi ekonomi.

Oleh karena itu, kegiatan pengabdian ini akan dilakukan di Kawasan Wisata Gili Meno. Kegiatan ini menekankan pada pelatihan kewirausahaan pasca bencana, terutama yang berkaitan dengan motivasi wirausaha dan mencari ide usaha. Tujuan dari kegiatan pengabdian yang dilakukan ini adalah untuk meningkatkan jiwa kewirausahaan bagi masyarakat sekitar dalam upaya pengembangan usaha pasca bencana gempa Lombok. Adapun manfaat yang diperoleh adalah dapat menumbuhkan semangat wirausaha pasca bencana bagi masyarakat Kawasan Wisata Gili Meno yang pada akhirnya dapat meningkatkan geliat usaha di kawasan wisata tersebut.

Permasalahan yang ada pada masyarakat Kawasan Wisata Gili Meno ini adalah masih adanya rasa trauma akibat bencana gempa yang terjadi pada tanggal 5 Agustus 2019 yang mengguncang Pulau Lombok. Rasa trauma tersebut mengakibatkan munculnya perasaan was-was dan enggan untuk melakukan sesuatu yang berkaitan dengan pekerjaan. Bencana tersebut juga 
memberikan dampak berupa banyaknya tempat usaha yang tutup karena rusak akibat gempa sehingga masyarakatnya banyak yang mencari pekerjaan di luar wilayah Gili Meno.

Solusi yang ditawarkan melalui kegiatan pengabdian ini adalah dapat meningkatkan motivasi masyarakat Kawasan Wisata Gili Meno untuk melakukan pengembangan usaha pasca bencana. Masyarakat juga diharapkan dapat memiliki kemauan, kemampuan dan membantu melakukan kegiatan usaha dengan memanfaatkan potensi sumber daya yang ada di wilayahnya.

Berdasarkan rencana kegiatan yang telah disusun, maka target luaran dari kegiatan pengabdian ini khususnya bagi masyarakat di Kawasan Wisata Gili Meno adalah sebagai berikut:

a. Masyarakat Kawasan Wisata Gili Meno menjadi termotivasi untuk melakukan kegiatan usaha yang dapat meningkatkan kondisi ekonomi masyarakat.

b. Masyarakat Kawasan Wisata Gili Meno mampu melakukan pengembangan usaha pasca bencana gempa Lombok.

\section{METODE KEGIATAN}

Seluruh rangkaian kegiatan dilaksanakan mulai dari bulan Mei sampai dengan November 2019. Pelaksanaan kegiatan dilakukan dengan cara sharing informasi, diskusi dan pendampingan kewirausahaan pasca bencana. Dalam kegiatan sharing inormasi, masyarakat kawasan wisata Gili Meno diberikan motivasi serta gambaran kondisi masyarakat di luar yang sudah mulai bangkit dari trauma agar semagat berwirausahanya tumbuh kembali dan secara perlahan menghilangkan trauma (Gladwell, 2008). Pada kegiatan diskusi juga dilakukan semacam trauma healing kepada para peserta pengabdian dengan mengajak mereka bermain games. Pendampingan dilakukan secara kontinyu dengan menjalin komunikasi melalui telepon dan/atau pesan singkat dengan masyarakat yang terlibat.

\section{HASIL DAN PEMBAHASAN}

\section{Pelatihan}

Kegiatan diskusi mengenai wirausaha pasca bencana ini dihadiri oleh beberapa warga yang tinggal di Kawasan Wisata Gili Meno. Dominan dari mereka adalah para pedagang, pegawai penginapan atau restaurant, dan pemilik usaha di seputaran Gili Meno. Peserta yang hadir sebanyak 25 orang yang memiliki usaha di kawasan wisata Gili Meno.

Kegiatan pelatihan kewirausahaan diisi dengan transfer knowledge kepada para peserta mengenai motivasi beriwirausaha. Materi mengenai motivasi berwirausaha yang dijadikan acuan selama kegiatan ini adalah materi motivasi berwirausaha karya Renhald Kasali (Kasali, 2010). Pemberian motivasi berwirausaha ini ditujukan agar masyarakat sekitar kawasan wisata Gili Meno tergerak kembali untuk menjalankan usahanya meskipun wisatawan yang berkunjung ke wilayah tersebut masih tergolong sepi jika dibandingkan dengan kawasan wisata gili lainnya (Gili Trawangan). Sebagian besar warga memilih untuk menghentikan sementara usahanya karena merasa sia-sia membuka usaha tetapi sepi pengunjung. Belum lagi banyaknya pegawai-pegawai yang dulunya bekerja di villa, penginapan, dan usaha-usaha lain di kawasan Gili Meno tersebut memilih untuk berhenti dari pekerjaannya dengan alasan tempat mereka bekerja yang lama tidak mampu untuk membayar mereka seperti biasanya dikarenakan kondisi keuangan yang sangat buruk pasca gempa.

Jika kondisi tersebut terus terjadi maka kawasan wisata tersebut akan semakin tidak menarik untuk dikunjungi. Selain itu, masyarakat juga akan kehilangan mata pencahariannya. Hilangnya mata pencaharian tersebut akan berdapak pula pada kondisi 
keuangan masyarakat. Mereka akan sulit untuk memenuhi kebutuhan hidup mereka akibat tidak memiliki salah satu alat pemuas kebutuhan berupa uang.

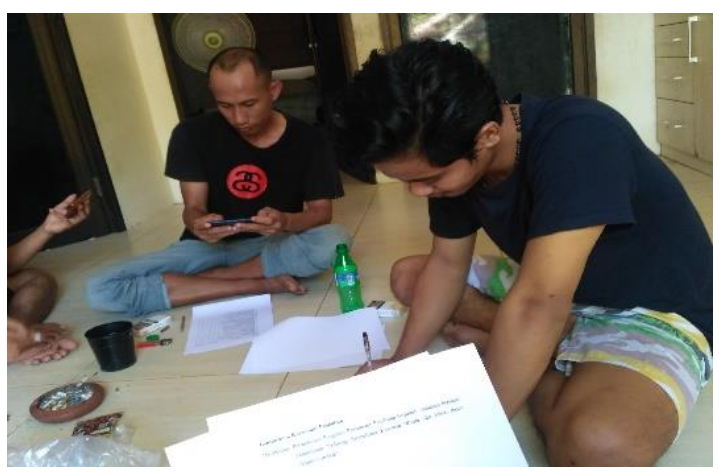

Gambar 1. Kegiatan Pelatihan

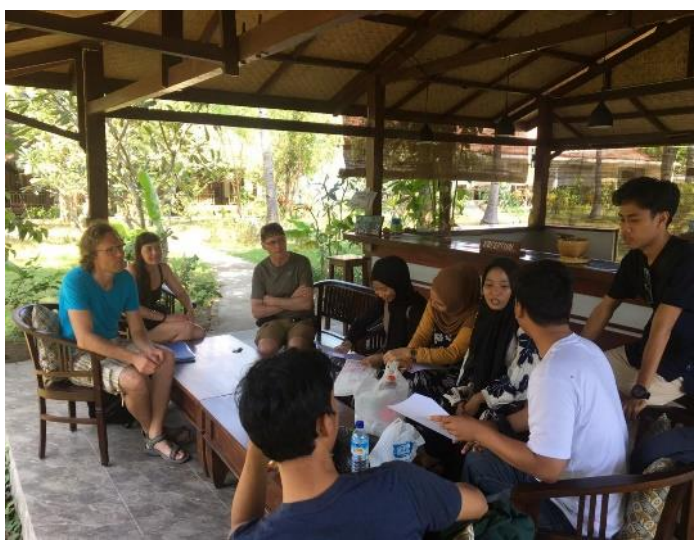

Gambar 2. Kegiatan Diskusi

Dalam proses sharing informasi ini ditekankan pula kepada masyarakat sekitar untuk berani mengambil risiko usaha. Setiap usaha pasti ada pasang surutnya, tetapi karakteristik utama dari seorang wirausaha adalah mampu bertahan ataupun bangkit dari keterpurukannya. Setiap usaha pasti memiliki risikonya masing-masing (Herrington dan Niehaus, 2004). Akan tetapi itu tidak dapat dijadikan sebagai alasan untuk terus terpuruk. Seorang wirausaha harus tetap mampu membuat usahanya bertumbuh dan berkembang. Apalagi kawasan wisata Gili Meno memiliki potensi pariwisata yang cukup menjual, terutama dikalangan wisatawan mancanegara.
Warga masyarakat kawasan wisata Gili Meno juga bisa menjadikan kondisi ini sebagai titik balik untuk membuat suatu usaha yang baru dengan cara merubah sudut pandangnya. Kondisi yang tidak baik tersebut jangan dijadikan alasan untuk mengehentikan usaha, tapi seharusnya dapat dilihatnya dari sisi yang berbeda. Misalnya, jika tidak ada bencana mungkin mereka tidak memiliki kesempatan untuk lebih memajukan usahanya dan tidak memiliki kesempatan untuk berpikir kreatif bagaimana agar usahanya tidak tergerus oleh kondisi yang buruk tersebut. Sekaranglah saatnya mereka mengubah sudut pandang yang mampu menghambat mereka untuk melakukan hal-hal positif yang nantinya akan mendatangkan banyak manfaat bagi masyarakat sekitar (Maxwell, 2007).

\section{Pendampingan dan Konsultasi Usaha}

Dari aspek wirausaha, masyarakat juga berkesempatan untuk membuat kombinasi usaha yang mungkin sedikit berbeda dengan sebelumnya agar usahanya tersebut menjadi lebih menarik dan mampu menarik wisatawan untuk berkunjung (Husein, 2001). Opsi lainnya adalah membuat usaha baru yang benar-benar berbeda dari usaha sebelumnya yang rusak akibat bencana gempa. Masyarakat bisa mempelajari atau melihat pengusaha lain yang dulunya pernah dilanda krisis yang sama namun mampu bangkit dan menjadi semakin sukses. Secara sederhana ada beberapa tips praktis yang bisa dilakukan oleh masyarakat selama mencari ide bisnis yang baru, diantaranya:

a. Seringlah mengikuti pameran perdagangan dan investasi. Hal ini karena mayoritas jenis usaha yang umum dilakukan oleh masyarakat kawasan wisata Gili Meno adalah berdagang, baik itu berupa produk barang mamupun jasa.

b. Pelajarilah keahlian tenaga kerja lokal. Sebagai wirausaha atau calon wirausaha, sangat penting untuk melihat kemampuan dan/atau keahlian dari tenaga kerja lokal. 
Hal ini bisa dijadikan sebagai input potensial untuk memulai usaha. Dengan menggunakan tenaga kerja lokal kita juga dapat meningkatkan taraf hidup masyarakat disekitar lokasi usaha.

c. Lakukan investigas material lokal dan sumber daya lain. Mulailah suatu usaha dengan cara yang paling sederhana terlebih dahulu, yaitu dengan cara memanfaatkan atau menggali potensi sumber daya terdekat yang ada disekitar. Tanpa disadari, sebenarnya di lingkungan sekitar tempat tinggal kita terkadang menyimpan sumber daya yang sangat potensial untuk dijadikan sebuah ide usaha. Apalagi untuk sebuah kawasan wisata pantai, begitu banyak potensi usaha yang dapat dimanfaatkan oleh masyarakat sekitar.

\section{KESIMPULAN DAN SARAN}

\section{Kesimpulan}

Berdasarkan pemaparan pada bagian sebelumnya maka dapat ditarik kesimpulan bahwa masyarakat kawasan wisata Gili Meno telah termotivasi untuk kembali membuka usahanya yang tutup pasca gempa Lombok dan mengajak sanak saudaranya yang sempat keluar atau pindah dari kawasan wisata Gili Meno untuk kembali memulai usahanya. Beberapa dari peserta pengabdian bahkan ada yang langsung membuat akun sosial media untuk menginformasikan bahwa kawasan wisata Gili Meno sudah aman dan bisa dikunjungi lagi sebagai wujud dari upaya pengembangan usaha yang dilakukan.

\section{Saran}

Adapun saran yang dapat diberikan terkait dengan kegiatan pengabdian ini adalah perlunya dilakukan kegiatan monitoring dan evaluasi agar dapat melihat progress dari masyarakat yang terlibat dalam kegiatan pengabdian. Selain itu, untuk kedepannya masyarakat yang telah memiliki usaha perlu diberikan pelatihan untuk membuat pembukuan sederhana terakait dengan operasioanal keuangan usaha.

\section{DAFTAR PUSTAKA}

Gladwell, M. 2008. The Story of Success. New York: Little, Brown and Company.

Harrington, Scott E., and Gregory R. Niehaus. 2004. Risk Management and Insurance $2^{\text {nd }}$ Edition. New York: McGraw Hill.

Kasali, Rhenald dkk. 2010. Modul Kewirausahaan Untuk Program Strata 1. Jakarta: Yayasan Rumah Perubahan

Maxwell, J.C. 2007. Talent Is Never Enough: Discover The Choices That Will Take You Beyond Your Talent. California: Thomas Nelson Inc.

Suryana. 2003. Kewirausahaan: Pedoman Praktis, Kiat dan Proses Menuju Sukses. Jakarta: Salemba Empat.

Peraturan Daerah Provinsi Nusa Tenggara Barat No.7 Tahun 2013 Mengenai Kawasan Strategis Pariwisata Daerah (KSPD) Provinsi Nusa Tenggara Barat. Rujukan: http://www.disbudpar.ntbprov.go.id/ka wasan-strategis/kawasan-strategispariwisata- daerah-kspd/ (diakses pada Tanggal 2 Maret 2018).

Umar, Husein. 2001. Studi Kelayakan Bisnis. Jakarta: P.T. Gramedia Pustaka Utama. 